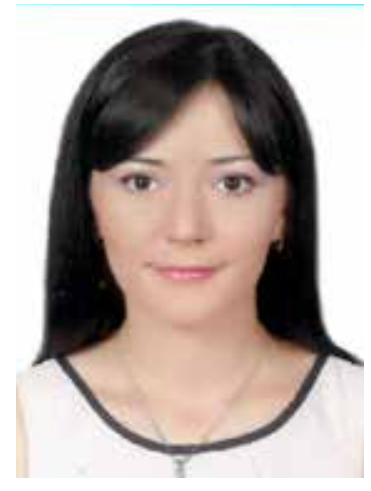

\author{
УАяна Коруи, \\ кандимат юридичних наук, \\ начальник вільілу міжнародних зв'язків \\ Тернопі^ьського національного \\ економічного університету
}

https://doi.org/10.32782/2020-38-09

УДК 343.33

\title{
Запобігання та протидія пропаганді війни та інформаційним загрозам в Україні
}

Актуальність теми. Україна фактично знаходиться у стані інформаційної війни, оскільки постійно є об'єктом інформаційної агресії, пропаганди (навіть невійськового, але негативного соціально-економічного та суспільно-політичного характеру) та тиску в усіх сферах суспільних відносин 3 боку Росії. Саме тому в таких умовах розробка та одночасна апробація механізмів і засобів протидії такі пропаганді відзначатимуть їх ефективність/ неефективність. Це створюватиме новий інструментарій протидії російській агресії, який при відповідному рівні узагальнення та уніфікації можна перетворювати на алгоритм протидії інформаційним загрозам, в тому числі інформаційній війні та відображати на рівні міжнародно-правових актів. Це підвищуватиме міжнародно-правовий авторитет України, оскільки ініціатива щодо закріплення на міжнародному рівні тих чи інших інструментів протидії інформаційним загрозам означатиме ефективне їх застосування Україною, а отже її здатність реалізовувати власний суверенітет, виступати самостійним повноцінним суб'єктом міжнародних відносин, протидіяти зовнішній агресії. Усе це підвищуватиме і рівень довіри до України з боку міжнародної спільноти та відновлюватиме той рівень підтримки у протидії всім проявам агресії з боку РФ, який українська держава мала на період 2014-2015 років.

За умови наявної постійної загрози з боку РФ, як військової, так і економічної, інформаційної тощо пропаганда війни стала активно використовуватися як засіб деструктуризації цілісного українського суспільства, що забезпечувалося формування усталеної ідеї протистоянню зовнішньому ворогу. Але застосування пропаганди війни саме як засобу ведення інформаційної війни проти України створює необхідність розгляду її як категорії супутньої із такими категоріями як власне «інформаційна війна» та «гібридна війна». Пропаганда як діяльність та як злочин сама по собі виступає складником іншого злочину - ведення 
війни, однак в силу того, що така війна ведеться в інформаційному просторі, то вона не має на сьогодні необхідного практичного закріплення як самостійний вид злочинної діяльності, а відповідальність за веденні інформаційної війни відсутня в національному кримінальному законодавстві.

Метою статті є дослідження та аналіз протидії та запобігання пропаганді війни та інформаційним загрозам в Україні.

Виклад основного матеріалу. Ураховуючи той факт, що на міжнародно-правовому рівні інформаційна війна досі не отримала необхідного закріплення та розроблення на рівні категоріального апарату, хоча i визнана як несумісна зі сталим розвитком ворожа, агресивна діяльність суб'єктів міжнародного права, однак практичних заходів протидії їй міжнародна спільнота не розробила. Це не повинно стримувати розвиток вітчизняної практики реалізації механізмів протидії пропаганди війни, особливо враховуючи той факт, що вона постійно зрощується 3 новими формами та проявами інформаційної війни проти України.

Така ситуація не означає недієвість чи низький рівень ефективності міжнародно-правових заходів і засобів протидії пропаганди війни для ï застосування в Україні, однак ми переконуємося в їх недостатності, а тому навіть враховуючи необхідність їх імплементації, слід доповнювати їх інструментами, механізмами, засобами та заходами, що мають стійку утилітарність в умовах України.

На думку ж О.О. Верголяс, сучасний рівень активізації діяльності 3 пропаганди війни перетворює іiі на основну інформаційну загрозу. Тобто на негативний інформаційний вплив технічного або психологічного характеру, що унеможливлює чи ускладнює збереження національних цінностей, реалізацію національних інтересів та досягнення національних цілей України [1, с. 205]. А тому можна свідчити про те, що пропаганда війни перетворилася на самостійний засіб ведення війни нової формації - інформаційної та гібридної війни.

Ми приєднуємося до думки вченого, що «інформаційна війна - це сукупність цілеспрямованих інформаційних впливів, що здійснюються суб“єктом впливу на інформаційні системи або соціальні процеси з використанням засобів інформаційних технологій, інформаційних ресурсів і комунікацій шляхом створення факторів гальмування сталого розвитку або трансформації стабільності держави, суспільства, людини з метою втримання (досягнення) панування, переваги, монополії в різних сегментах людського буття» [1, с. 205]. Тому вважаємо доцільним продовжувати на доктринальному рівні дослідження питання включення сукупності чи окремих із вказаних вище дій як протиправних та кримінально караних дій до національного кримінального законодавства.

Із цього приводу А.А. Головка акцентує увагу на тому, що низький рівень спроможності протистояти інформаційним загрозам, а також низька якість кримінального переслідування за скоєння злочинів пропаганди війни $є$ результатом «незавершеності процесу формування нормативно-правової бази забезпечення інформаційної безпеки (зокрема, перебування на стадії доопрацювання проектів законів «Про засади інформаційної безпеки України» та Концепції інформаційної безпеки України).

Вважаємо за необхідне повернутися до питання прийняття єдиного законодавчого акта у сфері протидії інформаційним загрозам України, протидії та переслідування пропаганди війни та забезпечення інформаційної безпеки в Україні. Цей закон повинен увібрати в себе основні принципи, в 
тому числі міжнародно-правові, щодо реалізації інформаційної безпеки, мінімізації військових та інших загроз в частині протидії пропаганди війни та будь-якої дискримінації у відношенні до української держави, українського народу тощо.

Зауважимо, що подібні спроби вже мали місце в 2014 році, коли актуальність протидії пропаганди війни була найвищою та найгострішою. Так, було зареєстровано Проекту Закону про засади інформаційної безпеки України № 4949 від 28.05.2014, який повинен був забезпечити основні засади державної політики, спрямованої на захист життево важливих інтересів людини і громадянина, суспільства і держави в інформаційній сфері, системи суб'єктів забезпечення інформаційної безпеки тощо [2]. Але його було знято з порядку денного.

Натомість було прийнято Закон України «Про внесення змін до деяких законодавчих актів України у зв'язку із прийняттям Закону України «Про інформацію» та Закону України «Про доступ до публічної інформації», який розроблено з метою приведення деяких законодавчих актів України у відповідність із законами України «Про інформацію» та «Про доступ до публічної інформації» [3].

Законом вносяться зміни до низки законодавчих актів України (4 кодекси та 53 закони України) з метою приведення їх у відповідність із законами України «Про інформацію» та «Про доступ до публічної інформації». Разом із тим вказаний вище закон не містить змін до відповідних кодексів, що звільняють посадових та службових осіб від відповідальностіза розкриття суспільно необхідної та іншої важливої інформації, що передбачено статтею 11 Закону України «Про доступ до публічної інформації» та статтею 30 Закону України «Про інформацію».

Але як зазначає I. Розкладай, пакет змін у понад 50 законів було розроблено ще в 2011 році групою експертів, проте 2 місяці виділені уряду по факту перетворилися на 3 роки: його прийняття відбулось лише 27 березня 2014 року. Така затримка спричинила «охолоджуючий ефект» для реалізації закону про доступ до публічної інформації, адже неузгодженість законодавства перешкоджала в реалізації прав, але водночас і не вирішувала проблем інформаційної безпеки в умовах вже на той час активної інформаційної війни 3 боку РФ [4]. Лише згодом з'являється Доктрина інформаційної безпеки України, прийнята Рішенням Ради національної безпеки і оборони України від 29 грудня 2016 року та затверджена Указом Президента України від 25.02.2017 № 47/2017. Але системний аналіз даної Доктрини, проведений нами в попередніх підрозділах, указав на недостатності заходів, які він передбачає, та недостатню ефективність наявних у частині реальної протидії пропаганді війни в України. Ця Доктрина є лише формою декларації та установчим актом у частині запровадження жорстких заходів боротьби із проявами ризиків в інформаційній сфері та інформаційним загрозам для України.

Крім того, сама форма цієї Доктрини - затвердженої Указом Президента України - вимагає додаткових заходів підвищення ефективності тих механізмів, які в ній запроваджені та прийняття додаткових нормативно-правових актів на їі виконання. Натомість прийняття спеціального закону дало б змогу активізувати розвиток кримінально-правового переслідування за злочини пропаганди війни, розширення ознак складу таких злочинів, їх диверсифікація та розширення на доктринальному рівні науки кримінального права інституту військових злочинів, який би доповнювався злочинами із пропаганди, підготовки та ведення інформаційної війни проти України. 
Ми наголошуємо на тому, що сучасний тренд у сфері державної політики забезпечення правового закріплення міжнародних механізмів протидії та кримінального переслідування за злочини у сфері пропаганди війни повинен зміщуватися не лише в бік ратифікації, приєднання та імплементації окремих норм і положень в національне законодавство, а й розроблення власних дієвих інструментів такої протидії.

Слід звернути увагу на думку низки вчених стосовно необхідності розробки поряд із Доктриноюінформаційної безпеки ще й Стратегії охорони психічного здоров'я нації. Так, наприклад, П.В. Волошин та Н.О. Марута вказують на «необхідність запобігання погіршенню психічного здоров'я i психологічного благополуччя численних верств населення, яке потребує системної спеціалізованої медико-психологічної допомоги» [5, с. 5]. Нам видається, що таке погіршення стало результатом негативного впливу на суспільство загроз інформаційної та національної безпеки з боку РФ. Україна дедалі частіше стає об'єктом інформаційної агресії, а тому пропаганда війни як один із їі елементів і спричинила подібні негативні наслідки, про які йдеться в дослідженнях вчених.

Така точка зору підтверджується у працях О. Олішевського, який зауважує на тому, що інформаційні загрози та пропаганда війни впливають в першу чергу на свідомість та психологічний стан людини, але їх наслідки $€$ значно системнішими [6, с. 158]. Вочевидь, йдеться про те, що, впливаючи негативним чином на свідомість людини та на суспільну свідомість у цілому засобами пропаганди війни, відбувається деформація суспільного сприйняття ролі держави, зростання стійкого переконання неспроможності держави захистити власний суверенітет та створити умови стійкої національної безпеки й стійкого безпекового середовища. Це призводить до нових форм реалізації злочинної діяльності з пропаганди війни, яка, трансформуючись, може зберігати цілі та засоби, але зміст діяльності виходить за межі можливостей їі кваліфікації як кримінально-караного діяння. У такому випадку явно протиправна та суспільно небезпечна діяльність випадає за межі можливостей кримінального переслідування.

Тому, на думку М.В. Маркової, Стратегія охорони психічного здоров’я нації або Стратегія забезпечення стабільного розвитку суспільної свідомості та правової культури «закріпили б обов'язковість міжвідомчої взаємодії та координації різних державних секторів, що опікуються питаннями психічного здоров'я; містила б програму структурної реформи інформаційного сектору; напрямки підвищення рівня правової культури та суспільної свідомості нації» [7, с. 8]. Ця теза синхронізується з висновком П.В. Пекара про те, що «пропаганда як вид злочину має конкретну прив'язку до суспільно небезпечних процесів або окремих актів, наслідки яких можуть стати суттєвою загрозою для міжнародного правопорядку. У цьому контексті пропаганда як міжнародний злочин визнається виключно стосовно конкретного акту, який сам по собі має негативні суспільні наслідки, в тому числі суттєве зниження рівня правової свідомості та правової культури, падіння державницьких настроїв та зниження рівня самоідентифікації нації» [8, с. 128]. Усе це в сукупності дає нам підстави стверджувати, що, окрім міжнародно-правових механізмів протидії пропаганди війни, в національному українському правовому полі повинні знайти своє відображення й механізми міжнародно-організаційного характеру. Йдеться про запровадження таких механізмів, які сприятимуть підвищенню рівня організаційної забезпеченості процесів протидії війни, оптимізуватимуть 
динаміку процесу протидії та координацію зусиль різних органів державної влади, чия владно-управлінська діяльність спрямована не лише на кримінальне переслідування, але і на створення засад попереджання пропаганди війни, моніторинг випадків їі появи в інформаційному просторі та захисту його від негативних наслідків зовнішньої агресії.

Цікавою тезою в контексті застосування у вітчизняній практиці протидії пропаганди війни міжнародних механізмів організаційного характеру є теза О. Шершньової стосовно необхідності розробки нових складів злочинів, таких як: «інформаційний тероризм», «інформаційна блокада», «кібертероризм» та ін. Таке розширення можливостей кримінологічної кваліфікації протиправних діянь дасть змогу розробити чітку і єдину концепцію захисту інформаційного простору держави, а також уточнить національні орієнтири й ідентифікацію інформаційної безпеки як на внутрішньо-локальному, так і на міжнародному рівні [9, с. 37].

Той факт, що сучасний КК України визначає пропаганду війни як кримінальне правопорушення проти миру, безпеки людства та міжнародного правопорядку, дає всі підстави стверджувати про можливість розроблення нової родової сукупності злочинів у сфері інформаційної та гібридної війни, оскільки сьогодні пропаганда війн все частіше розглядається саме як елемент останньої, особливо враховуючи практичний характер окремих проявів такої війни з боку РФ по відношенню до України, який має сучасні негативні наслідки для міжнародного правопорядку та регіональної безпеки у Східній Європі.

Інформаційну війну, як суспільно-політичне негативне явище, розглядає О.В. Курбан, розробляючи при цьому методологічне забезпечення іiі протидії та концептуалізуючи окремі складові елементи такої війни. Зокрема, дослідником піднімаються питання віднесення пропаганди війни не лише до складового елементу інформаційної війни, а до системних деформацій інформаційного простору та суспільної свідомості, коли пропаганда війни сприймається як ціннісний орієнтир подальшого розвитку державно-суспільних процесів [10, с. 128-133]. Така структурна деформація означає низький рівень ефективності організаційно-правового забезпечення протидії пропаганді війни, неефективність державної політики в даному сегменті безпекового простору, а також піднімає питання про стійку потребу в пошуках нових потенційних джерел підвищення ефективності вказаних дій.

До речі, в Україні вже запроваджена Стратегія кібербезпеки України, яка була схвалена Рішенням Ради національної безпеки і оборони України від 27 січня 2016 року та затверджена Указом Президента України від 15.03.2016 № 96/2016. Але сьогодні, як слушно зазначає Г.Ф. Хорунжий, першочерговими завданнями повинні стати уточнення та посилення кримінально-правового забезпечення державної політики протидії пропаганди війни, яка повинна розроблятися та запроваджуватися на підставі вивчення досвіду окремих закордонних країн [11, с. 12, 14].

Наявність окремих недоліків відповідного спрямування чинних юридичних документів, недостатня увага нормативно-правовому врегулюванню державно-громадської взаємодії у протидії інформаційним загрозам» - все це створює передумову не лише імплементації міжнародно-правових заходів забезпечення інформаційної безпеки, але і розроблення Україною та спробами запровадження в міжнародну практику тих інструментів протидії пропаганді війни, які підтверджують свою ефективність у сучасних реаліях України. 
Висновки. Ми доходимо висновку, що правове закріплення будьяких механізмів, заходів, засобів міжнародно-правової відповідальності чи заходів протидії пропаганди війни обов'язково повинно мати відповідний супровід на рівні національного законодавства, ефективність лише міжнародно-правового переслідування буде недостатньою без наявності легальних підстав застосування до особи, що скоїла злочин у вигляді пропаганди війни, заходів державного примусу в межах кримінального переслідування та притягнення до кримінальної відповідальності. Лише це характеризуватиме ефективність системи протидії таким злочинам.

Сучасний тренд у сфері державної політики забезпечення правового закріплення міжнародних механізмів протидії та кримінального переслідування за злочини у сфері пропаганди війни повинен зміщуватися не лише в бік ратифікації, приєднання та імплементації окремих норм і положень в національне законодавство, а розроблення власних дієвих інструментів такої протидії. А прийняття спеціального закону дало б змогу активізувати розвиток кримінально-правового переслідування за злочини пропаганди війни, розширення ознак складу таких злочинів, їх диверсифікацію та розширення на доктринальному рівні науки кримінального права інституту військових злочинів, який би доповнювався злочинами із пропаганди, підготовки та ведення інформаційної війни проти України.

\section{Список використаних джерел}

1. Верголяс О.О. Правове забезпечення спеціальних інформаційних операцій : дис. к.ю.н. : спеціальність 12.00.07. - Київ : НДІІП НАПрН України, 2020. 287 с.

2. Проект Закону про засади інформаційної безпеки України. URL : http://w1.c1.rada.gov.ua/pls/zweb2/webproc4_1?pf3511=51123.

3. Про внесення змін до деяких законодавчих актів України у зв'язку з прийняттям Закону України «Про інформацію» та Закону України «Про доступ до публічної інформації» : Закон України від 27.03.2014 № 1170-VII. URL : https://zakon.rada.gov.ua/ laws/show/1170-18\#Text.

4. Розкладай I. Як Україна протидіє інформаційній агресії Pociї. URL : https://cedem.org.ua/articles/yak-ukrayina-protydiye-informatsijnij-agresiyi-rosiyichastyna- $2 /$.

5. Олішевський О. Заходи протидії пропаганді війни в Україні. Jurnalul juridic national: teorie şi practică = Национальный юридический журнал: теория и практика. 2018. № 1, T. 1 (Februarie). C. 155-160.

6. Маркова М.В. Інформаційно-психологічна війна: медико-психологічні наслідки та стратегії протидії. Проблеми безперервної медичної освіти та науки. 2016. № 4. С. 6-10.

7. Пекар П.В. Пропаганда війни в законодавстві про кримінальну відповідальність пострадянських країн. Наше право. 2016. № 2. С. 125-130.

8. Шершньова О. Нормативно-правове забезпечення національної безпеки країни та вплив сучасних інформаційних викликів і загроз інформаційній безпеці. Актуальні проблеми міжнародних відносин та зовнішньої політики : матеріали III Регіональної науково-теоретичної конференцї (Львів, 24 березня 2016 р.). Львів : НУ ЛП, 2016. C. $36-38$.

9. Курбан О.В. Сучасні інформаційні війни в мережевому он-лайн просторі. Київ : ВІКНУ, 2016. $286 \mathrm{c}$.

10. Хоружий Г. Ф. Війна Росії проти України: російська пропаганда як складова «гібридної війни». Украӥнський науковий журнал. 2016. № 4. С. 6-15. 


\section{Коруц У. З. Запобігання та протидія пропаганді війни та інформаційним загрозам в Україні \\ У статті обгрунтовано, що Україна фактично знаходиться у стані інформаційної} війни, оскільки постійно є об'єктом інформаційної агресії, пропаганди (навіть невійськового, але негативного соціально-економічного та суспільно-політичного характеру) та тиску в усіх сферах суспільних відносин з боку Росії. Саме тому в таких умовах розроблення та одночасна апробація механізмів і засобів протидії такі пропаганді відзначатимуть їх ефективність/неефективність. Це створюватиме новий інструментарій протидії російській агресії, який за умови відповідного рівня узагальнення та уніфікації можна перетворювати на алгоритм протидії інформаційним загрозам, у тому числі інформаційній війні, та відображати на рівні міжнародно-правових актів.

Автор концентрує увагу на необхідності прийняття єдиного законодавчого акта у сфері протидії інформаційним загрозам України, протидії та переслідування пропаганди війни та забезпечення інформаційної безпеки в Україні. Цей закон повинен увібрати в себе основні принципи, в тому числі міжнародно-правові, щодо реалізації інформаційної безпеки, мінімізації військових та інших загроз у частині протидії пропаганди війни та будь-якої дискримінації у відношенні до української держави, українського народу тощо.

Наголошено, що сучасний тренд у сфері державної політики забезпечення правового закріплення міжнародних механізмів протидії та кримінального переслідування за злочини у сфері пропаганди війни повинен зміщуватися не лише в бік ратифікації, приєднання та імплементації окремих норм і положень в національне законодавство, а розроблення власних дієвих інструментів такої протидії.

Обгрунтовано важливість запровадження таких механізмів, які сприятимуть підвищенню рівня організаційної забезпеченості процесів протидії війни, оптимізуватимуть динаміку процесу протидії та координацію зусиль різних органів державної влади, чия владно-управлінська діяльність спрямована не лише на кримінальне переслідування, але і на створення засад попереджання пропаганди війни, моніторинг випадків її появи в інформаційному просторі та захист його від негативних наслідків зовнішньої агресії.

Той факт, що сучасний КК України визначає пропаганду війни як кримінальне правопорушення проти миру, безпеки людства та міжнародного правопорядку, дає всі підстави стверджувати про можливість розробки нової родової сукупності злочинів у сфері інформаційної та гібридної війни, оскільки сьогодні пропаганда війн все частіше розглядається саме як елемент останньої, особливо враховуючи практичний характер окремих проявів такої війни з боку РФ по відношенню до України, який має сучасні негативні наслідки для міжнародного правопорядку та регіональної безпеки у Східній Європі.

Правове закріплення будь-яких механізмів, заходів, засобів міжнародно-правової відповідальності чи заходів протидії пропаганди війни обов'язково повинно мати відповідний супровід на рівні національного законодавства. Ефективність лише міжнародно-правового переслідування буде недостатньою без наявності легальних підстав застосування до особи, що скоїла злочин у вигляді пропаганди війни, заходів державного примусу в межах кримінального переслідування та притягнення до кримінальної відповідальності. Лише це характеризуватиме ефективність системи протидії таким злочинам.

Ключові слова: інформаційна війна, пропаганда, пропаганда війни, злочин, агресія, інформаційна безпека.

Koruts U. Preventing and counteracting the propaganda of war and information threats in Ukraine

The article substantiates that Ukraine is in fact in a state of information war, as it is constantly the object of information aggression, propaganda (even non-military but negative socio-economic and socio-political nature) and pressure in all spheres of public relations from Russia. That is why in such conditions the development and testing of 
mechanisms and means of counteraction to such propaganda will note their effectiveness / ineffectiveness. This will create a new tool for counteracting Russian aggression, which, with the appropriate level of generalization and unification, can be transformed into an algorithm for counteracting information threats, including information warfare, and reflected at the level of international legal acts.

The author focuses on the need to adopt a single legislative act in the field of combating information threats to Ukraine, counteracting and persecuting war propaganda and ensuring information security in Ukraine. This law should incorporate basic principles, including international law, regarding the implementation of information security, minimization of military and other threats in terms of combating war propaganda and any discrimination against the Ukrainian state, the Ukrainian people, etc.

It is emphasized that the current trend in public policy to ensure the legal consolidation of international mechanisms for combating and prosecuting crimes in the field of war propaganda should be shifted not only towards ratification, accession and implementation of certain norms and provisions in national legislation, but also the development of effective tools.

The importance of introducing such mechanisms that will help increase the level of organizational support of the war response process, optimize the dynamics of the counteraction process and coordinate the efforts of various government agencies, whose management activities are aimed not only at criminal prosecution, but also at creating war prevention and monitoring principles. cases of its appearance in the information space and its protection from the negative consequences of external aggression.

The author conducts a detailed analysis and defines that the fact that the current Criminal Code of Ukraine defines war propaganda as a criminal offense against peace, security of mankind and international law gives all grounds to argue about the possibility of developing a new generic set of crimes in the field of information and hybrid warfare, because today war propaganda is increasingly seen as an element the latter, especially given the practical nature of certain manifestations of such a war on the part of the Russian Federation in relation to Ukraine, which has current negative consequences for international law and order and regional security in Eastern Europe.

In addition, the author focuses on the legal consolidation of any mechanisms, measures, means of international legal responsibility or measures to counter the propaganda of war must be accompanied by appropriate support at the level of national legislation. the effectiveness of international law prosecution alone will be insufficient without the existence of legal grounds for the application to a person who has committed a crime in the form of propaganda of war, measures of state coercion within the framework of criminal prosecution and prosecution. Only this will characterize the effectiveness of the system of counteraction to such crimes.

Key words: information war, propaganda, war propaganda, crime, aggression, information security. 